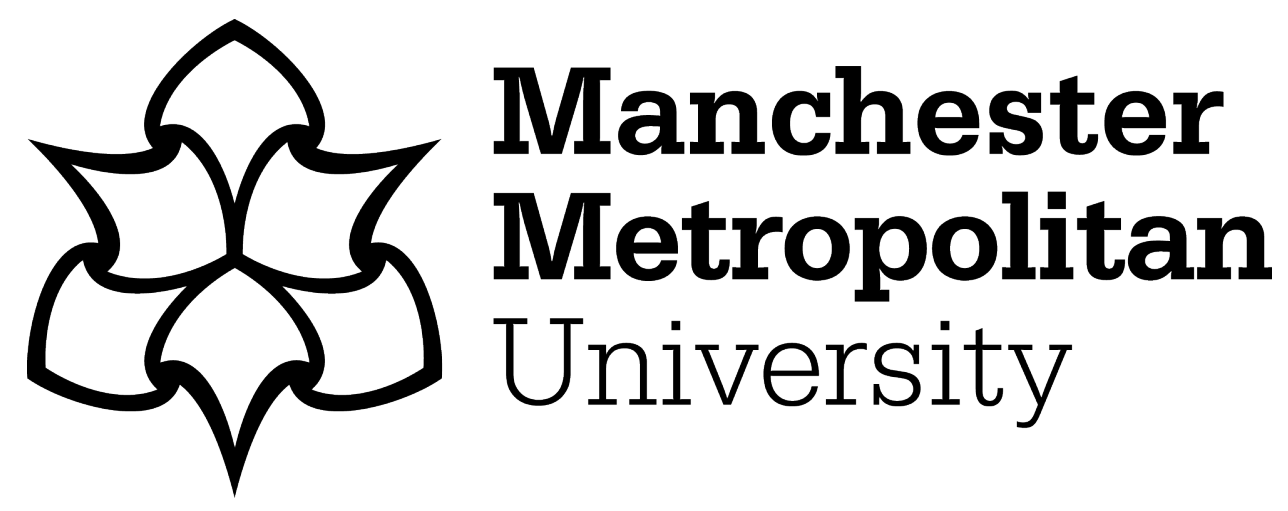

Salerno, Joseph T, Dorobat, Carmen-Elena ORCID logoORCID: https://orcid.org/0000-0003-3343-6786 and Israel, Karl-Friedrich (2020) Two views on neutral money: Wieser and Hayek versus Menger and Mises. European Journal of the History of Economic Thought, 27 (5). pp. 682-711. ISSN 0967-2567

Downloaded from: https://e-space.mmu.ac.uk/625137/

Version: Accepted Version

Publisher: Taylor \& Francis (Routledge)

DOI: https://doi.org/10.1080/09672567.2020.1739106

Please cite the published version 


\title{
Two views on neutral money: Wieser and Hayek versus Menger and Mises
}

\author{
Joseph T. Salerno \\ Emeritus Professor of Economics \\ Lubin School of Business, Pace University \\ One Pace Plaza, New York, New York 10038 \\ jsalerno@pace.edu
}

Carmen Elena Dorobat*

Senior Lecturer in Strategic Management

Manchester Metropolitan Business School SES

All Saints Campus, Oxford Road, Manchester, United Kingdom M16 6BH

c.dorobat@mmu.ac.uk

\author{
Karl-Friedrich Israel \\ Institute for Economic Policy, University of Leipzig \\ Grimmaische Straße 12, 04109 Leipzig, Germany \\ karl-friedrich.israel@uni-leipzig.de
}

*corresponding author

\begin{abstract}
Neutral money plays a central role in contemporary macroeconomic theory, and is a live issue in recent monetary policy discussions. We challenge the opinion that Hayek's writings on neutral money have been influenced by, and are similar to, the work of Menger and Mises. We show, first, the significant alternative influence of Friedrich von Wieser on Hayek's work on the subject. Second, we rehabilitate a neglected method of monetary theorizing specific to Menger and Mises that rejects money neutrality both as a tool for investigating monetary phenomena and as the standard by which monetary regimes, and the market economy itself, should be evaluated. Examining this chapter in the history of economic thought can aid in a deeper reconsideration of the doctrinal foundations of modern monetary theory and policy.
\end{abstract}

Keywords: neutral money; monetary equilibrium; barter economy; Wieser; Hayek; Mises; Menger

JEL Codes: B53; E13; E31 


\section{Introduction}

Over the last two centuries, economists have postulated the separation of the real and monetary aspects in economic analysis on the basis of one fundamental principle: the neutrality of money. Modern scholars acknowledge that Friedrich A. Hayek was the first economist to employ the term neutral money to clearly designate a state of affairs in which money does not exert an active influence on the determination of real variables. Hayek's work in the early 1930s, notably Prices and Production (Hayek 1967 [1935]), gave the concept of neutral money currency among English-speaking economists (Lutz 1969).

In at least two publications in the early 1930s, however, Hayek (1967 [1935]: 129, 1984 [1933]: 160) also stated that both Carl Menger and Ludwig von Mises had discussed the problem of neutral money under the label of money's "inner objective exchange value" (innere objektive Tauschwert), or the "inner value of money" (innere Geldwert) for short. Although Hayek never explicitly claimed that either man attributed analytical or normative significance to the concept, there subsequently arose a widespread tendency to ascribe a strong kinship between Mises and Hayek in the formulation of the neutral-money doctrine (Horwitz 2016: 62; 65). ${ }^{1}$ The Hayekian version of the neutral money concept was then described as the central concept of Austrian business cycle theory, originated by Menger, and developed by Mises and Hayek (Roll 1936: 458).

This paper seeks to challenge this account of the development of the neutral money concept by analysing the differences between the views of the three authors-Menger, Mises,

\footnotetext{
${ }^{1}$ For example, in his book on German Monetary Theory, Ellis (1934: 460) listed "Mises, 337-38," under the "Neutral money" entry in the book's subject index, despite the fact that neither the term nor the concept appears in the discussion of Mises's business cycle theory on these pages. Ellis (1934: 335), however, did make the telling statement a few pages earlier, "For the full development of Mises' theory it is necessary to study the work of Hayek." Similarly, in his textbook, which was intended as a summary of "the present state of the debate in monetary theory" circa 1940, Georg Halm (1946, ix: 379) included Mises among "some theorists" whose analysis of the business cycle started from the proposition that cyclical fluctuations would not occur under "the assumption of a neutral behaviour of money."
} 
and Hayek - on the issue. In doing this, we aim to rehabilitate a forgotten alternative way of monetary theorizing that was developed by Menger and Mises and rejects money neutrality both as a tool for investigating monetary phenomena and as the standard by which monetary regimes, and the market economy itself, should be evaluated. Furthermore, our investigation will also show that no accounts have fully explored the significant alternative influence of Friedrich von Wieser on Hayek's work on the neutral money doctrine. As we shall see, Wieser-Hayek's teacher at the University of Vienna and his formative influence in general economic theory ${ }^{2}$ - had in fact originated the concept of neutral money that Hayek further explored in his own work.

To this end, the paper is structured as follows: Friedrich von Wieser, as the originator of the neutral-money doctrine is treated first in section 3, and Friedrich A. Hayek, his student and two generations his junior, is examined next in order to highlight the essential identity of their views on neutral money. Ludwig von Mises, who was of the generation of Viennese economists between Wieser and Hayek, is dealt with in section 5 to clearly emphasize the contrasting attitudes toward the neutral-money concept and the distinct manner of theorizing between Hayek and Mises. Finally, Carl Menger is considered last in order to highlight the link between his and Mises's views of the possibility and desirability of implementing a monetary policy in which money is rendered strictly neutral to the pricing process of a dynamic market economy.

In our view, this historical investigation is important at present for a proper understanding and continued reconsideration of neutral money. Before delving into the works of the four authors, let us first explain why tracing back the conceptual origins and development of the neutral money concept can help us achieve clarity on current doctrinal and policy matters.

\footnotetext{
${ }^{2}$ On Wieser's personal relationship with Hayek and his profound and persistent influence on Hayek's thought, see Salerno (1999: 42-3) and Salerno (2002).
} 


\section{Why does neutral money matter?}

The analytical tool of neutral money came to play a central role in the development of modern macroeconomic theory (Klein 1947, Samuelson 1958). According to Patinkin and Steiger (1989: 137) the term itself, "neutral money", often used interchangeably with the expression "veil of money", "did not come into use until the interwar period, primarily as the result of the work of Hayek and Koopmans in the early 1930s.” Friedrich A. Hayek (1967 [1935]: 129) himself gave credit primarily to Knut Wicksell for coining the term, to the German economist W. G. Behrens for first using it in a context similar to his own, and to the Dutch economist J. G. Koopmans (1933) for publishing the first comprehensive analysis of the concept. Laidler (1990) however, traced the term as far back as Wicksteed in 1910, who referred to the "covering cloak of monetary payments"; Klausinger (1990) found it first in Schumpeter's 1908 Habilitation thesis, while Boianovsky (1993) traced it further to BohmBawerk and Fisher. Schumpeter (1968: 264-5, 313-4, 561) in turn, considered neutral money (or the 'money veil') to be a customary expression and a defining feature of the orthodox economics which had been built on insights from David Ricardo and John Stuart Mill as an implication of the classical dichotomy between monetary or nominal values, and real values, or real riches, that putatively holds in the long run. ${ }^{3}$

The construct of an imaginary barter economy was first used only in conducting a preliminary analysis of market-price determination before the emergence of money. However, the construct further evolved into a reference model for an actual monetary economy in which, although hypothetical, "a frictionless pure exchange economy without money" (Chaloupek 2010: 1) became normatively relevant as an efficiency standard. This

\footnotetext{
${ }^{3}$ See, for example, Mankiw (2003: 107-8) and Abel and Bernanke (1992: 139).
} 
was supported by the assumption that in a market monetary economy, "natural values" or "real prices" lie beneath money prices.

The concept of the 'monetary veil' then allowed for changes in the value of money (e.g. as a result of a change in the money supply) to have no long-term effects on the distribution of resources and wealth, or on relative commodity prices, and thus for any potential short-term consequences to be dismissed as transitory. After the rational expectations revolution (Lucas 1975, Sargent and Wallace 1976), it became widely accepted that only real changes affect real decisions, and that variations in the purchasing power of money are neutralized if correctly anticipated (McCallum 1980) — not only in the long run, but in the medium and short run as well (Kaldor 1970, Lines and Westerhoff 2010).

Notwithstanding this distinction ${ }^{4}$ in the use of the term "neutral money", the assumption that changes in the quantity of money cause no change in the relative prices of goods is based on the same premise of the existence of natural values under the monetary veil. For all intents and purposes, the tension between the two conceptualisations is only superficial—or rather, a difference in emphasis, but not in kind. For Hayek, as we will see later on, the ideal monetary economy replicates the natural values of prices from the ideal barter equilibrium. For Patinkin (1965: 75) and Patinkin and Steiger (1989: 138), "in the absence of money illusion"- that is, in not employing a questionable comparison between a barter economy and a monetary economy, but in using barter only as a limiting position for a money economy — we can, however,

"get as "close" as we want to a barter economy without affecting the equilibrium values of these variables and hence of real outputs. In this sense, these values in a money economy are the same as they would be in a barter economy. $[\ldots][\mathrm{H}]$ owever . . . as the nominal quantity of money approaches zero, so does the price level - and at the same rate. Thus the limiting position that we have defined as a barter economy is one in which there exists the same

\footnotetext{
${ }^{4} \mathrm{We}$ are grateful to the anonymous referee who suggested clarifying this distinction.
} 
real quantity of money as in a money economy! This drawback

notwithstanding, there does not seem to be any other meaningful way of

comparing the respective equilibrium positions of a money and a barter

economy" (Patinkin and Steiger (1989: 138).

As we shall see in the paper, Mises, influenced by Menger, rejected neutral money both as a theoretical tool and as the normative standard, because it refers, in both cases - albeit with a different emphasis - to an unrealizable barter economy. While the construct of an imaginary barter economy is valuable in conducting a very preliminary analysis of market-price determination, it is normatively irrelevant to the historical market economy, which "is real because it can calculate" (Mises 1966: 259) — and thus irrelevant to elucidating the workings of monetary policy. Once money, the tool of economic calculation, comes into existence it does so with a market of its own and therefore exerts a driving force or dynamic influence on all economic quantities.

Neutral money is at present very much a live issue in monetary policy discussions around the level of the neutral interest rate ${ }^{5}$ and the goals of monetary policy. The political and academic consensus - of pursuing stabilization policies (of output or employment), as well as structural reforms of labour and capital markets, while anchoring the value of the monetary unit to a steady, fully anticipated rise in the price level-has its roots in the acceptance of the long-run neutrality of money. Any monetary policy that keeps prices rising constantly around announced levels is considered neutral to relative prices and real income levels, capturing otherwise idle market resources, such as unemployed labour.

\footnotetext{
${ }^{5}$ The Wicksellian natural rate of interest is defined as the rate which "is neutral in respect to commodity prices, and tends neither to raise nor to lower them. This is necessarily the same as the rate of interest which would be determined by supply and demand if no use were made of money and all lending were effected in the form of real capital goods" (Wicksell 1962 [1936]: 102; emphasis added). In modern times, however, monetary policy makers use the rather opposite concept of the Keynesian neutral rate, in order to gauge "when the federal funds rate reaches a level consistent with full employment of labor and capital resources over the intermediate run" (Yellen 2005: 11). For a discussion of the differences between Wicksell and Keynes on this point, cf. Salerno (2016).
} 
Furthermore, what the neutral interest rate is (Williams 2003, Pescatori and Turunen 2015), its time-varying characteristics (Öğünç and Batmaz 2011, Williams 2015) and how to measure it (Laubach and Williams 2015, Lubik and Matthes 2015), or how to fine tune a neutral monetary policy (Perrelli and Roache 2014) have also become intensely discussed topics, especially in the period after the 2008-2009 financial crisis (Chetwin and Wood 2013, Milhoj and Fischer 2015) and in relation to the monetary policy of the U.S. Federal Reserve (Hamilton et al. 2015, Federal Reserve Bank of New York 2016).

In response to these developments, research into the non-neutrality of money has also reached a critical mass of works and theories, with scholars seeking to bridge the divide between real and monetary phenomena, and to apply these new insights to recent historical experience. According to various Post Keynesian and New Keynesian theories, money neutrality does not hold because there are macroeconomic inefficiencies in the real economy that hinder its adjustment to new nominal values following movements in the value of money (Meltzer 1988), even if the latter can be correctly anticipated. Scholars have further nuanced these discussions to include rigidities concerning transmission of information about purchasing power (Mankiw and Reis 2002) or "money stickiness", i.e. a transitory nuisance of monetary injections reaching market participants gradually rather than simultaneously (Cheng and Angus 2012). However, the postulate of money neutrality is still included in the main assumption of these studies, i.e., that the real economy does not adjust — as it shouldto the nominal levels of variables. In this case, theoreticians postulate implicitly, if not explicitly, that it is still both theoretically and practically meaningful to distinguish between money prices and real relative prices. In other words, both modern supporters and opponents of the neutral money concept operate in fact within the same money neutrality paradigm, which seems to have swept the economics profession into a rare agreement. 
In this context, retracing and clarifying doctrinal divergences between Mises and Hayek can help shed new and welcome light on current issues in monetary policy by strengthening and sharpening the debate surrounding neutral money and monetary policies that aim at making money neutral. As we shall see, the arguments put forth in the Mengerian and Misesian view not only challenge the neutral money concept, but do so from a radically different economic and monetary perspective than current critiques of the postulate, as both economists took an unfavourable view of the theoretical soundness and the practicability of the concept for monetary theory and policy. On the other hand, Hayek's concept of neutral money-derived from the work of Wieser, and now widely accepted-invoked the desirability of a neutral monetary system. Even so, Wieser and Hayek both originally had reservations regarding the practical usefulness of such a system-another neglected point which can help nuance current discussions on the issue even further.

\section{Friedrich von Wieser}

The gist of the neutral-money concept first emerged from Wieser's attempt to integrate money into his analysis of the "social" or market economy. The efficiency standard Wieser formulated to evaluate the performance of the social economy was based on his preliminary analysis of a centrally directed, moneyless economy that he called a "natural value" or "simple" economy whose endogenous variables were determined purely by real factors. ${ }^{6}$

Although, his writings on monetary theory have been overshadowed by his contributions to value and distribution theory, Wieser was a monetary theorist of no mean ability or breadth of vision. ${ }^{7}$ Hayek (1992 [1926]: 122) himself characterized Wieser's writings on money and credit "as nearly as suggestive for future research and equally full of

\footnotetext{
${ }^{6}$ Wieser distinguishes between the "Theory of the Simple Economy" (a purely communistic economy) and the "Theory of the Social Economy" (the unhampered exchange economy). Cf. Wieser (1967 [1927], pp. 9-12).

${ }^{7}$ This paper only deals with one aspect of Wieser's monetary thought. For surveys and critiques of Wieser's overall monetary theory, see Anderson (1917: 74-9), Greidanus (1932:119-23), Ellis (1934: 81-7, 176-80), Dullart (1988) and Hülsmann (2007: 225-36).
} 
new insights" as his price theory. His view was echoed by Schumpeter (1968: 1086, 1969: 300) and Sennholz (1992: 5), while other doctrinal studies (Greidanus 1932: 119, Ellis 1934: 176, Marget 1966, 1: 336-9) have identified Wieser as one of the originators of the income theory of money.

In analysing and evaluating the performance of a money-exchange economy, Wieser (1971 [1893]: 37) originated the concept of natural value, which refers to an equilibrium structure of relative marginal utilities that would emerge in "a community at a high stage of development carrying on its economic life without price or exchange.” Wieser (1971 [1893]: 62) also defined natural value as "the value which would be recognized by a completely rational and united commonwealth." He then implicitly established such a static communist or "simple" economy as the criterion to be applied in appraising the efficiency of the market economy by seeking to "investigate closely to what extent the phenomena of exchange value are of natural origin." Abstracting from the inequality of the distribution of "financial power" that inevitably attends the operation of the market economy, Wieser concluded that the introduction of exchange and, then, money into the analysis, in and of itself, does not yield a structure of money prices that are inconsistent with the underlying real equilibrium of natural values. As Wieser (1967 [1927]: 235-36) explained:

The process of the formation of prices is much more diverse than that of the appraisal of values in the model simple economy, because of the introduction of many new factors. ... But whatever new elements we have had to introduce into our investigation have not brought with them any new forces. Even the new element, money, is merely an instrument to effect exchange movements of natural values.

However, according to Wieser, money departs from its purely intermediary and neutral role and exerts a driving force of its own — to use Mises's term—whenever its value fluctuates. Thus, for instance, a fall in the value of money would involve a disturbance of the real or 
natural economy by a one-sided supply of money, as Hayek referred to it, i.e., by a purchase of goods that has not been immediately preceded by a sale of goods. Moreover, the outcome of this initial disturbance, argued Wieser (1967 [1927]: 282), is not merely instability in the value of money but destabilization of the real economy itself:

By the depreciation of money all prices are affected. The prices are permanently increased; the value of money is permanently changed. Because its value becomes permanently unstable, money functions with constant friction. The plan of all private and public economies is adjusted to the presupposition of the constancy of the value of money; money is given and received by those who assume that in the future it will have the same purchasing power as it has here and now. When this assumption proves incorrect many expectations remain unfulfilled, numerous economies are disorganized and more than one is ruined.

Indeed, in his very last article on the theory of money, his "closing economic work", 8 that was published shortly after his death in the $4^{\text {th }}$ edition of the famous Handwörterbuch der Staatswissenschaften, Wieser (1926: 705) made his position very clear by calling the people's confidence in a constant value of money the "indispensable condition of the normal use of money" (die unerläßliche Voraussetzung des normalen Gelddienstes). These observations were made with the inflationary tendencies of the interwar period in mind. But inflation and the resultant depreciation of money were not the only possible problem for a monetary system.

The effects of the appreciation of the monetary unit can be even more devastating in Wieser's view. In fact, an increase in the cash-balance demand for money, ceteris paribus, can set in motion a universal business depression that would wreck the economy before the

\footnotetext{
${ }^{8}$ The other editors of the Handwörterbuch (Wieser was actually one of them) state in a brief postface to the article that Wieser himself referred to it as his "ökonomische Schlußarbeit." Hans Mayer had to do the final editorial work prior to publication. This encyclopedia entry is of great interest for our investigations, since Carl Menger was the author of the entry on money in the first three editions of the Handwörterbuch. Only after Menger's death did Wieser assume the task. Their respective expositions allow for a direct and illuminating comparison, as we will see below.
} 
requisite rise in the value of money could be completely consummated. According to Wieser (1967 [1927]: 285), "the appreciation of money would thwart the anticipations of every business man, would depress all sales prices and would decrease or wipe out all expected profits... it would become impossible to recover costs incurred and would bring in its train a universal crisis that would be more ruinous than any crisis engendered by overproduction in particular industries." Such a crisis could not simply be caused by a general increase in the supply of goods or "general overproduction" as some proponents of the quantity theory argued and whose views Wieser decidedly rejected. ${ }^{9}$ Instead, it could be caused by a general increase in the demand for money. Only the latter would lead to a genuine appreciation of money and its potentially very harmful effects.

While Wieser (1967 [1927]: 286) thus denied "the contention that increased commercial intercourse may lead to an appreciation in the value of money," he affirmed that a fall (or rise) in the general price level reflecting an increase (or decrease) in the scarcity of goods due to changes in technology or capital and resource availabilities is possible and perfectly consistent with money's function as an accurate and stable measure of price. The lower prices should then "properly be interpreted as an expression of the decreased value of goods" (Wieser 1967 [1927]: 286) due to the law of marginal utility. In the Handwörterbuch, he explicitly states that, even under the most rational monetary system, one could not prevent all changes in the purchasing power of money that are "the result of an intensification of economic processes" (die Folge der Intensivierung des volkswirtschaftlichen Prozesses) (Wieser 1926: 717).

Wieser argued, however, that while an expansion in metallic or paper fiat currency may_-viz., in the absence of an equivalent increase in the demand for money_precipitate a

\footnotetext{
${ }^{9}$ For a critical discussion of the quantity theory, see also Wieser (1929 [1909a]: pp. 212ff.). In this essay as well as the associated lecture delivered at the Vienna meeting of the Verein für Socialpolitik the same year, Wieser 1929 [1909b] emphasized the importance of carefully distinguishing between the different causes of changes in the exchange value of money: they can come from the goods side as well as the money side, and their implications are very different.
} 
process of depreciation, monetary depreciation does not generally result from an increase in fiduciary media, i.e., bank notes and deposits unbacked by the money commodity. This is because an emission of fiduciary media by banks does not exercise the same alleged onesided influence on exchange as gold discoveries or fiat-money issues. Thus, bank credit expansion does not displace the market economy from its natural value equilibrium.

According to Wieser (1967 [1927]: 280-1), "Credit media come and go with the movement of commodities in business; they sublimate the natural values and are their companion values in monetary form." Put differently, credit media of exchange are backed by business activity (geschäftlich gedeckt, see Wieser (1926: 690)). ${ }^{10}$

In enthusiastic recognition of the service they render in maintaining the neutrality of the monetary system with respect to the natural economy, Wieser (1967 [1927]: 281) offered a paean to privately issued fiduciary media, while anticipating, and perhaps inspiring, his student Hayek's enthusiasm for spontaneous social institutions:

...they afford one of those surprising examples of free, individualistic, yet social institutions which are more perfectly adjusted to the general interest than would be possible through the most thoroughly considered, purposeful contrivances of the state. The voluntary organization of credit has achieved what no regulation of state-contrived monetary systems has heretofore been able to attain: a standard which receives its quantitative norm from the service of money itself.

In contrast to the production of gold, which proceeds under the spur of private entrepreneurial profit seeking, and may under certain conditions cause disequilibrating effects of the resulting monetary inflation, Wieser (1967 [1927]: 281) concluded, "credit-money fulfils the spirit of money as enlightened statesmanship would determine it." Despite these considerations, however, Wieser (1967 [1927]: 281-2) admitted that, left to the private market, bank credit creation could be and had been abused, interfering with "the equation of demand and supply,"

\footnotetext{
${ }^{10}$ This is reminiscent of the British Banking School's "law of reflux", which Wieser (1967 [1927]: 245, 247; Dullaart 1988: 125) fully accepted. See also Wieser (1926: 694).
} 
provoking "overproduction" and culminating in "liquidation crises." Other shortcomings of fiduciary media are that, first — at least at the time Wieser was writing — their circulation does not penetrate to all income classes and economic regions (e.g., wage-earners and rural areas) and, second, their increase presupposes additional reserves of "ready money" (in current terminology, base money). These circumstances imply that, even assuming the benign responsiveness of fiduciary media, for an increase in the demand for money to be fully neutralized, "increased amounts of ready money are necessary" (Wieser 1967 [1927]: 286).

For Wieser (1967 [1927]: 276-7), consequently, the ideal system for ensuring monetary neutrality would be a State-issued fiat currency:

"If once the state would issue it, no longer in its own immediate and selfish interest, but solely in order to substitute a well regulated monetary symbol for the costly, inconvenient hard money, which depends so much on the results of the production of the precious metals... The notes would take over the exchange value of the coin in the place of which they would appear. They would retain this value without being exposed to the disturbances which... have their origin in the production of the precious metals."11

\footnotetext{
${ }^{11}$ Elsewhere, in the German original, Wieser (1926: 716) describes his ideal monetary system in the isolated economy in the following way:

Es kann kein Zweifel darüber bestehen, daß überall dort, wo man im Verkehre bereits an Noten gewöhnt ist - und wo wäre man das nicht! - das Papiergeld auf dem Markte den überlieferten Tauschwert des alten Geldes in geschichtlicher Kontinuität fortsetzen wird. Das neue Papiergeld wird nicht nur alle bestehenden Metallgeldschulden bezahlen, sondern auch auf dem Markte so viel kaufen wie das alte Metallgeld. Die Vorteile einer solchen Geldordnung sind einleuchtend. Die Masse des vorhandenen Währungsmetalls wird zu anderer Verwendung frei, man erspart die fortlaufenden Kosten seiner Erneuerung, das neue Geld ist der Gefahr der Depreziation entzogen, die von der reicheren Ergiebigkeit der Geldproduktion droht, und ebenso ist das Geldwesen von den Beengungen frei, die von der Erschöpfung der Goldproduktion zu befürchten wären; denn der Staat kann dem steigenden Geldbedarfe eines steigenden Verkehres mitentsprechender Erhöhung seiner Notenausgabe entgegenkommen.
}

In our own translation, it reads:

There can be no doubt that wherever you are already used to notes in circulation - and where wouldn't you be! - the paper money on the market will continue to be exchanged at the value of the old money in historical continuity. The new paper money will not only pay all existing metal money debts, but will also buy as much on the market as the old metal money. The advantages of such a money order are obvious. The mass of the existing money metal becomes free for other purposes, one saves the ongoing costs of its renewal, the new money is 
Unfortunately, in the case of paper money, "the mass habit of acceptance" which is necessary to initiate and maintain a currency in circulation cannot extend beyond the domestic economy of the issuing nation-state. As a result, a strictly national fiat money will always be subject to fluctuating exchange rates, which would disturb the natural value of real goods and services in international trade. Gold, from this point of view, is "the less objectionable evil because it best secures an international constancy of values; it is thus preferable to the best regulated paper-money confined to a single state" (Wieser 1967 [1927]: 277).

To sum up, the neutral-money doctrine - in its embryonic Wieserian formulationargues that the standard of efficiency to be applied in evaluating the performance of the historical money-exchange or market economy is the pattern of relative values and resource allocations that would emerge in the exchange-less, centrally controlled simple economy with an identical constellation of real economic data. In Wieser's view, given that entrepreneurs are looking back in time, and their automatic production decisions are governed by past prices, a change in the supply of or demand for money that is unmatched by a change in the overall supply of goods and services promotes a destabilization of the real (natural) economy.

Additionally, he believed a one-sided decrease of the money-spending stream (as Hayek referred to the issue), in particular, will initiate an adjustment process that will culminate in a devastating depression and contraction of real economic activity rather than in a smooth transition to a higher value of money. While privately-issued fiduciary media can be an important means for spontaneously moderating deflationary adjustment processes, their imprudent and ill-timed issue is likely to continually recur, displacing relative prices from their equilibrium natural values and precipitating a boom-bust cycle of overproduction and

freed from the danger of depreciation, which emanates from higher yields of money production, and likewise the monetary system is free from the restrictions, which would have to be feared from the exhaustion of gold production; because the state can meet the increasing need for money due to increasing circulation with corresponding increases of its note issue. 
business liquidation. Finally, the real-world monetary regime that would, in principle, come closest to embodying the features of Wieser's ideal money is a paper fiat money issued by a supranational central bank. However, in a world of sovereign nation-states, the gold standard with its feature of fixed exchange rates will yield a price system that more closely approximates the system of natural values than a regime of freely fluctuating national fiat currencies. ${ }^{12}$ In fact, the stabilization of exchange rates was of very high importance to Wieser (1926: 714ff.). ${ }^{13}$

\section{Friedrich A. Hayek}

Hayek's formulation of the neutral money concept was inspired—perhaps unconsciously, as he himself tells us_-by his teacher Wieser (Hayek 1984 [1933]: 160). For Hayek's neutralmoney doctrine is, in its essentials, nothing more than an attempt to elaborate the precise conditions under which Wieser's one-sided influence of money would never emerge to drive relative prices away from their general-equilibrium configuration.

Hayek (1992 [1926]: 116-7) thus accepted in his earlier writings the static (shadow) price system implicit in Wieser's simple or centrally directed economy as the starting point for his own analysis. According to Hayek (1984 [1933]: 159), in developing the concept of neutral money, he sought to "isolate the influences which money actively exerts upon the economic process, and to establish the conditions under which [this process and] relative prices are not influenced by any but 'real' determinants - where 'real' relates to the equilibrium theory developed under the assumptions of barter." As we have shown above, the pure exchange efficiency standards and the assumption that changes in the quantity of money

\footnotetext{
${ }^{12}$ Wieser (1926: 717) writes: "Ein Weltpapiergeld ist heute eine Utopie. Unter den geschichtlich gegebenen Umständen ти $\beta$ das Weltgeld auf der Goldbasis verbleiben." [own translation: A world paper money today is a utopian idea. Under the historically given circumstances, world money must remain on the gold base.]

${ }^{13}$ The importance of a money with internationally stable exchange value has also been pointed out in Wieser's (1929 [1904]: 167) inaugural lecture at the University of Vienna.
} 
cause no change in the real, relative prices of goods are based on the same premise of the existence of natural values under the 'monetary veil'.

Having accepted the Wieserian standard for an efficiently operating monetary economy, Hayek deduced that any change in the volume of money-by which he meant "the volume of the money stream" or "quantity times the velocity of circulation" (Hayek 1966 [1933]: 92 fn.) — disrupts the equilibrium of the real economy. Hayek (1966 [1933]: 108, emphasis added) expressed the point in clearly Wieserian terms: ${ }^{14}$

changes in the volume of money have... a one-sided influence which elicits no reciprocal adjustment in the economic activity of different individuals. By deflecting a single factor, without simultaneously eliciting corresponding changes in other parts of the system, it dissolves its 'closedness,' makes a breach in the rigid reaction mechanism of the system (which rests on the ultimate identity of demand and supply) and opens a way for tendencies leading away from the equilibrium position.

Although there is some ambiguity on this point, it appears in his earlier writings (roughly prior to 1931), Hayek upheld constancy of the money stock as the ideal policy norm, willingly accepting the implication that overall prices should fall in the face not only of an increase in real output that resulted from an enhancement of technology or factor supplies, but also as a consequence of an increase in the demand for cash balances (White 1993: 1416). Indeed, Hayek (1978: 84) confessed in his later years, that "at one stage" he believed that an increase in the demand for liquidity on the part of the community at large would "justify,

\footnotetext{
${ }^{14}$ With his notion of the "one-sided influence", Hayek in a sense generalizes the Wieserian term "einseitiges Geldangebot [one-sided supply of money]" (Wieser 1929: 178). In his Social Economics, Wieser clearly lays out the meaning of the one-sided supply of money as follows:
}

"The equation of supply and demand is disturbed by the increase in the quantity of money. The demand, which originates from the money form, increases, but the supply of natural values [goods] remains the same. Neither the gold miner who has struck an exceedingly rich deposit or the state which issues paper money in huge quantities are under any compulsion to introduce beforehand into the economic organism natural values in equal amounts which would prepare the ground for their demand. They appear as purchases [sic, purchasers] in a market which they have never entered as sellers. Therefore they do not meet ready sellers without disturbing the market" [Wieser 1967 [1927]: 280; emphasis added). 
and even require, that the value... of money should rise compared with that of commodities." ${ }^{15}$ In terms of the equation of exchange, Hayek thus had at first maintained that a practical approximation to neutral money required that $M$ remained constant, while $P$ fell in response to a fall in $V$ as well as to a rise in $Y$.

However, in a footnote to Monetary Theory and the Trade Cycle, Hayek (1966 [1933]: 92 fn.) redefined the "volume of money" so that it no longer referred to a stock, "the quantity of money in circulation," but rather denoted a flow, "the volume of the money stream." He refers to the first edition of Prices and Production published in 1931, where this flow definition was in fact already adopted. ${ }^{16}$ Thus constancy of the stream of money payments now became for Hayek, as it had been for Wieser, the hallmark of neutral money. This point was reiterated in the Preface to the second edition of Prices and Production (published in 1935), and again in the text, where Hayek (1967 [1935]: xii-xiii, 124) concluded that "any change in the velocity of circulation would have to be compensated by a reciprocal change in the amount of money in circulation if money is to remain neutral towards prices."

Wieser had maintained that the historical value of money rigidly conditioned entrepreneurial expectations of its future value. Hayek similarly argued that entrepreneurs myopically formulate their expectations and production plans on the basis of current prices, and therefore past configurations of relative prices. Therefore, should a pattern of prices develop that reflects the transient influence of a one-sided change in the volume of money, the effect will be an almost automatic misallocation of resources. This was especially the implication in his later writings - despite his efforts to "dynamize" the Wieserian concept of

\footnotetext{
${ }^{15}$ See for example his early article on The Paradox of Saving, first published in German in 1929 and later translated and published in Economica in 1931, where Hayek (1969: 262) emphasized that "every increase in the volume of money" results in a disarrangement of the productive apparatus.

${ }^{16}$ Even though the German edition of Monetary Theory and the Trade Cycle was initially published in 1929, the footnote in question was one of "the numerous minor alterations and additions" Hayek (1966 [1933]: 15) said he made to the English edition because the footnote refers to Prices and Production published in 1931. For confirmation of this, see Hayek (2012, p. 98 fn. 49).
} 
general equilibrium — where Hayek sought to portray the price system as a means for disseminating dispersed knowledge to decentralized producers. According to Hayek (1978: 82):

successful economic action... depends largely on the approximately correct prediction of future prices... based on current prices and the estimation of their trend, but [which are]... to some degree uncertain because the circumstances which determine them will be unknown to most individuals. [Prices communicate] signals of changes of which the individual cannot know but to which his plans must be adjusted. This system works because on the whole current prices are fairly reliable indications of what future prices will probably be.

It is important to recognize that Hayek's depiction of the price system as a vehicle for disseminating knowledge depends crucially on his Wieser-inspired vision of the market economy as really operating in close proximity to the state of long-run equilibrium. Hayek (1952 [1941]: 27-8) explicitly states that "observation" reveals that "real conditions," to some extent, "approximate towards a state of equilibrium... and that the functioning of the existing economic system will depend on the degree to which it approaches such a condition." Neutralizing the one-sided influences of money was for Hayek (1978: 82), then, absolutely necessary for maintaining the integrity of the system of relative price signals and thus avoiding the systematic and, ultimately, unsustainable diversion of the pattern of resource employment from its equilibrium configuration:

current prices of particular commodities... can be positively misleading if they are caused by non-recurring events, such as temporary inflows or outflows of money to the system. For such apparent changes in demand... systematically channel productive efforts into directions where they cannot be maintained.

Early in his career, it is true, Hayek was almost exclusively concerned with explicating the non-neutral effects of an increase in the volume of money, in the form of the boom-bust cycle. Indeed, he came to be seen in the early 1930 s as a "deflationist" or "liquidationist" 
because he opposed any attempt to combat the depression by renewed credit expansion (Hayek 1966 [1933]: 19-22). In 1932, he had argued against Keynes that inflationary policies were not advisable to counterbalance secondary deflation if its underlying cause is a previous maladjustment of the structure of production (Hayek 1995 [1932]: 194) ${ }^{17}$. But even during this period Hayek (1966 [1933]: 19) expressed no doubt that "an indefinite continuation of [the present] deflation would do inestimable harm." Hayek argued later that the only reason for which he had accepted deflation as a temporary measure was of a political nature, i.e., because he believed at the time that "a deflation might be necessary to break the developing downward rigidity of all particular wages which has of course become one of the main causes of inflation" (Hayek 1985: 210).

As the depression wore on, Hayek focused his attention increasingly on the issue of deflation. In Monetary Nationalism and International Stability, published in 1937, he reckoned as one of the "well-known defects of gold" and "a problem of major importance" changes in the value of gold threatened by "violent changes in the conditions of its production or the appearance of a large new demand for it" (Hayek 1971 [1937]: 75-6). In 1943, Hayek (1972 [1943]: 215) set forth a scheme for a commodity reserve currency, which would stabilize commodity prices and "would also go far to stabilize the demand for manufactures and to prevent the [incipient] depression from becoming serious." By 1975, shortly after receiving the Nobel Memorial Prize for economics, Hayek had completely abandoned any deflationist position:

I would no longer maintain, as I did in the early '30s, that for this reason, and for this reason only [rigidity of wages], a short period of deflation might be desirable. Today I believe that deflation has no recognizable function

\footnotetext{
${ }^{17}$ Selgin (1999) argues that Hayek's view was a "productivity norm" type of anti-inflationism, different from the extreme deflationist view that was attributed to him by later commentators. Due to this, Selgin (1999: 719) claims that Keynes and Hayek were much more similar in their views: "Hayek came at last to accept a view of optimal price level behavior that was practically the same as the one he had found wanting in Keynes almost half a century before. And Keynes... acknowledged on more than one occasion the merits of a productivity norm, which Hayek had embraced in the early 1930s."
} 
whatever, and that there is no justification for supporting or permitting a process of deflation. [...] The moment there is any sign that the total income stream may actually shrink, I should certainly not only try everything in my power to prevent it from dwindling, but I should announce beforehand that I would do so in the event the problem arose (Hayek 1975: 5; 12-3). ${ }^{18}$

Regarding the optimal monetary system from the standpoint of its approximation to the theoretical ideal of monetary neutrality, Hayek initially followed Wieser's rankings of the gold standard and various kinds of fiat-money regimes. Like Wieser, he accorded the highest rank to a fiat money operated under the circumstances of "a securely established world State with a government immune against the temptation of inflation" (Hayek 1971 [1937]: 74-5). However, without such a world state and given the non-neutral effects on relative prices, interest rates, and international capital flows caused by fluctuating exchange rates, Hayek (1971 [1937]: 75) argued that "while an international standard is desirable on purely economic grounds, the choice of gold with all its undeniable defects is made necessary entirely by political considerations." Nevertheless, Hayek's Wieserian aversion to the disturbing, one-sided effect of money on the equilibrium system of relative prices achieved by real forces continually inspired him to devise practical alternatives to the international gold standard. As we noted above, in 1943, he took up the cudgels in defence of a commodity reserve currency, which was designed to meet the "really serious objection against gold... the slowness with which its supply adjusts itself to genuine changes in demand" (Hayek 1972 [1943]: 211). In the twilight of his career, Hayek (1978: 106) was touting the virtues of competing, stable-value fiat currencies issued by private firms, which "can do much better than gold ever made possible" and whose low cost and uncomplicated system of provision

\footnotetext{
${ }^{18}$ By 1978, in New Studies in Philosophy, Politics, Economics and the History of Ideas (1985: 210-11; emphasis added), Hayek had made it clear again: "Though I am sometimes accused of having represented the deflationary cause of the business cycles as part of the curative process, I do not think that was ever what I argued."
} 
"made it appear as at least more practicable than... a commodity reserve standard." ${ }^{19}$ Hayek's most mature scheme of monetary reform thus featured "denationalized" and competitivelyissued fiat moneys (Hayek 1978: 84-5), and was partly designed to avoid the one-sided effects of deflation by responding to an increase in the demand for liquidity by increasing the stock of money.

\section{Ludwig von Mises}

By the late 1930s, the neutral-money doctrine had come to exercise a strong hold on the minds of prominent monetary economists and the educated public, a hold which has only grown since then. Although Mises's work has been identified as the inspiration for or, at least, bearing a close kinship with the Hayekian formulation of the neutral money doctrine, Mises denied responsibility for originating the concept, and in fact challenged both its soundness and its usefulness in monetary theory or policy:

I myself am not responsible for the term 'neutral money'... coined by later authors... I must protest the belief that it has to be a goal of monetary policy to make money neutral and that it is the duty of the economists to determine a method of doing so. I wish to emphasize that in a living and changing world, in a world of action, there is no room left for a neutral money. Money is nonneutral or it does not exist (1990 [1938]: 77).

In the first edition of the Theorie des Geldes und der Umlaufsmittel, originally published in 1912, the second edition of which was somewhat misleadingly translated into English as The

Theory of Money and Credit, Mises explains that

\footnotetext{
${ }^{19}$ It should be noted that Hayek - unlike Mises, for example — considered the creation of fiduciary media as an endogenous and necessary outcome of the operation of socially-evolved monetary and financial institutions and practices, especially the issue of fiduciary media by fractional reserve banks. According to Hayek (1966 [1933]: 141-2), "this elasticity in the volume of money is an immanent characteristic of our present money and credit system..., an inherent necessity of the existing money and credit system that its reaction to certain changes in data is different from what we should expect on the basis of economic equilibrium theory." Hayek thus gave a Wieserian twist to business cycle theory, portraying cyclical phenomena as one of the various dislocations of the barter equilibrium equation of supply and demand brought about by the one-sided supply of money.
} 
money that is inserted as an intermediary between the other exchangeable goods is not merely a neutral link in the chain of exchange acts leading from the producer to the consumer. It also changes the position of the parties on the market. The medium of exchange is an economic good like any other; as such it is subject to an independent movement of values, and to the extent that this has not been included in the calculation by the purchaser and the seller or is contrary to their expectations, the success they have sought will not be achieved in exchange. [...] In the mechanism of the exchange organization operates a force that can, under certain circumstances, shift the relationship of the exchanging parties; here is a source from which arise losses for some and profits for others (Mises 1912: 469; own translation).

From this, Mises draws an unambiguous conclusion:

This error certainly weighs quite heavily and no conceivable organization of indirect exchange can avoid it. Since indirect barter is a necessary phenomenon in the exchange economy based on the division of labour, these shortcomings are inextricably linked to it. No reform has been able to eliminate them. The ideal of money of unchangeable internal objective exchange value is unattainable and will remain so forever (Mises 1912: 46970; own translation)..$^{20}$

Mises's views on these issues are also clearly shown in three essays following the first German edition of The Theory of Money and Credit, where Mises discussed in practical terms

\footnotetext{
${ }^{20}$ In the German original we read:

Das Geld, das sich als Tauschvermittler zwischen die anderen Verkehrsgüter einschiebt, ist nicht lediglich ein neutrales Zwischenglied in der Kette der Tauschakte, die vom Produzenten zum Konsumenten führt; es ändert nicht unwesentlich die Stellung der Parteien auf dem Markte. Das Tauschmittel ist ein wirtschaftliches Gut wie jedes andere; es ist als solches einer selbständigen Wertbewegung unterworfen, und soweit diese vom Erwerber und vom Veräußerer nicht in den Kalkül mit einbezogen wurde oder ihren Erwartungen entgegen verläuft, wird im Tausche nicht jener Erfolg erreicht werden, den sie angestrebt haben. [...] Im Mechanismus der Austauschorganisation wirkt eine Kraft, die das Verhältnis der tauschenden Parteien unter Umständen zu verschieben vermag; hier ist eine Quelle, aus der für die einen Verluste, für die anderen Gewinne entstehen. [...]

Dieser Fehler wiegt gewiß recht schwer und keine denkbare Organisation des indirekten Tausches vermag ihn zu vermeiden. Da der indirekte Tausch eine notwendige Erscheinung in der arbeitsteilig produzierenden Verkehrswirtschaft ist, sind diese Mängel untrennbar mit ihr verknüpft. Keine Reform vermochte sie zu beseitigen. Das Ideal eines Geldes von unveränderlichem innerem objektiven Tauschwert ist unerreichbar und wird es ewig bleiben.
} 
the general rise in prices, monetary devaluation, and purchasing power policies of that time (Mises 2012 [1913a, 1913b; 1919]). Written before Hayek became a regular attendee in Mises's privatseminar in Vienna ${ }^{21}$, Mises describes in these essays, in detail, the gradual and uneven effects of changes in the value of money on relative prices and the distribution of wealth (2012 [1913b]: 161-62)—a phenomenon later coined 'Cantillon effects'. Although he did not use the term neutral money or Cantillon effects at the time, Mises employed the same analysis, almost word for word, as in his 1938 lecture titled "The Non-Neutrality of Money" (Mises 1990 [1938]: 80).

For example, in 1913, Mises explained that monetary devaluation “...only appears gradually throughout the economy. The prices of various goods do not rise proportionally all at once. Inflation first appears in some particular part of the economy, affecting only some goods, and then gradually spreads out from there... This gradual progression of rising prices causes its associated effects. The particular social groups who first receive the new quantity of money benefit from the process, while those are harmed who receive the money only later in the process" (Mises 2012 [1913a]: 142-43)

He made the same point six years later, in 1919:

“...changes in the purchasing power of a nation's currency do not take place immediately and do not occur at the same time in regard to all goods... The additional quantity of money appears somewhere in the economy, and then spreads out gradually. At first, it flows only into certain businesses and certain branches of production, raising the demand for only certain goods and services, and not all of them; later, the prices for other goods and services also start to rise" (Mises 2012 [1919]: 236).

These insights were then reiterated in subsequent writings, originally published in 1924 (Mises 2002 [1924]) and 1931 (Mises 2002 [1931]), and two essays from 1944 (Mises 2000

\footnotetext{
${ }^{21}$ Hayek joined the seminar in 1924, after reading Mises's book, Socialism, first published in 1922. Ebeling (2014: 143) explains that the topics of money and prices were often discussed: "when Hayek was participating he delivered presentations on the theory of imputation, credit and banking policy, price level stabilization, and a variety of related subjects." Hayek moved from Austria to the UK to teach at LSE in 1931.
} 
[1944a] and 2000 [1944b]). Mises also discusses his views briefly in criticizing Fisher's compensated dollar plan in Monetary Stabilization and Cyclical Policy (2006 [1928]:85-88)

before he fully explored it in Human Action (Mises 1966 [1949]). For instance, Mises emphasized that

"If all commodity prices and wage rates were to rise at the same time and to the same extent, even violent changes in the purchasing power of the monetary unit would be economically neutral and would not affect the income and the wealth of the citizens. But this condition can never occur... Some classes of prices and wages rise more quickly and to a steeper level than others. This unevenness is the main source of the social consequences of inflation" (Mises 2000 [1944a]: 75).

This shows that Mises's views on the social consequences of inflation not only remained consistent throughout his scholarly work, but that Hayek was exposed to these views as early as the 1920s. However, as we shall see more clearly in what follows, Mises's monetary theory exerted only little influence on Hayek's writings, which more closely followed Wieser's views on these issues, as we described before. ${ }^{22}$

The main reason for these differences between Mises on the one hand, and Wieser and Hayek on the other, is the fact that the analytical basis of Mises's opposition to the neutral money framework was rooted in an alternative tradition of monetary theorizing that

\footnotetext{
${ }^{22}$ Hayek used Cantillon effects in his analysis of the business cycle as a "leitmotiv" in his critique of alternative monetary theories (Hagemann and Trautwein 1998: 293). However, as Hagemann and Trautwein (1998) show, his adaptation of Cantillon is different from Mises's in two ways: first, Hayek's primary focus on the structure of production and investments neglects the role of expenditures for consumption, making Cantillon effects in the Hayekian interpretation (i.e. forced savings) a special case of the more general distributional and allocative effects (Hagemann and Trautwein 1998: 303). For Mises, however, both consumption and investment are equally important transmission channels of inflation, and in both channels Cantillon effects show the gradual and uneven adjustment of prices following an increase in the money supply. This leads to the second difference between Mises and Hayek,: while for Hayek, the crisis—and thus Cantillon effects during the boom — could be avoided via compensatory voluntary savings to finance investments ex-post (Hagemann \& Trautwein 1998: 304), for Mises the Cantillon effects in the upswing of a crisis can only be compounded by the Cantillon effects of a post-financing of malinvestments, but never compensated (Mises 1990 [1938]) . For Mises, therefore, the non-neutrality of money is taken into account in its full distributional and allocative effects, thus dispersed, gradual and uneven among individual cash balances that any attempts at smoothing out the effects of a credit expansion are doomed to fail. See also Salerno (2012) for a brief discussion of the difference in emphasis between Mises and Hayek on malinvestment and overconsumption during a business cycle - difference in emphasis which in our view is due to Hayek's restricted application of Cantillon effects to investments.
} 
may be called the monetary calculation tradition and that, as we shall see in the last section, was originated by Carl Menger. The arguments put forth in this view not only challenge the neutral money concept, but do so from a radically different economic and monetary perspective than current critiques of the postulate we discussed in the first part of this paper.

Let us now detail and contrast this alternative view with that of Wieser and Hayek.

The Misesian approach was based on the fundamental insight that "money prices are the only vehicle of economic calculation" (Mises 1966: 201). As Mises argued in the socialist calculation debate of the 1930 s, without recourse to economic calculation using the cardinal numbers provided by actual money prices, there would be no possibility of rationally allocating or "economizing" scarce resources. But Mises's argument also implied that the concept of a barter economy with developed capital markets and a temporally lengthy and technologically intricate structure of production is a "fiction"- an imaginary construct useful only for the elaboration of elementary price theory (Mises 1966: 201). Analysing the formation of prices employing the "barter fiction," as Mises called it, is essential for highlighting the fact that all market phenomena are traceable back to individuals' subjective rankings of utilities, "to the universal category of preferring $a$ to $b$," and that, therefore, "what is ultimately exchanged is always economic goods of the first order against other such goods" (Mises 1966: 201-2). In reality, however, a direct-exchange economy, lacking a common medium of exchange by definition, would not permit the emergence of a structure of homogeneous and commensurable economic quantities necessary for calculation of the relative scarcities and most valuable employments of the factors of production.

In particular, Mises argued, the interest rate, while not fundamentally a monetary phenomenon, can only find expression in a monetary economy. In the absence of monetary exchange, there would exist no unitary market for savings, and, therefore, each good would have a unique "own rate" of interest, rendering the ascertainment of the pure rate of interest 
or social rate of time preference impossible, and investment in the structure of production chaotic. Mises (1990 [1932]: 65) thus explained that "[i]n a barter economy, the phenomenon of interest could never be isolated from the evaluation of future price movements of individual goods. To assume the existence of a highly developed market system without the intermediation of a generally accepted means of exchange would be a scientific fiction."

Moreover, according to Mises (1966: 210-1; 230; 260-2; 491; 514-5), money prices generated by the historical market process give meaning to the very concept of capital and the related concept of income. In a barter economy, just as in a socialist economy, actors would be unable to quantify their capital and income or even to conceive the distinction between them. That is, lacking a common unit for expressing the market value of goods, they would be unable to discern whether a plan of present consumption out of current output impaired their capacity to produce for future wants, left it unchanged, or enhanced it. For example, without the aid of monetary calculation as expressed in capital accounting, an entrepreneur would be at a loss in ascertaining what proportion of the gross receipts of his business he would be free to expend on his personal consumption without at the same time consuming his capital.

In sum, Mises rejected monetary neutrality. The concept of neutral money refers exclusively to an unrealizable barter economy. Consequently, it should neither guide monetary theory nor should it be held up as a normative standard for monetary policy. Barter offers no means for economic calculation of profit and loss, for the conceptual, let alone quantitative, grasp of capital and income, or for the unitary expression of the interest rate and of the quantity of saving. But once money comes into existence it does so with a market of its own and therefore exerts a driving force or dynamic influence on all economic quantities. Only money prices ever have a real, if momentary, existence in the historical market economy, and these prices necessarily reflect the ever-changing relation between the supply 
of and demand for the money commodity. The reason is that this "money relation," as Mises called it, is embodied in — and indeed actualizes - the interdependent system of supply-anddemand relations in the individual markets for non-monetary commodities.

It should be pointed out briefly before proceeding that Mises's conception of the purchasing power of money generated by the historical market process, explained in the regression theorem, is fundamentally different from the Wieserian historical value of money. ${ }^{23}$ In the 1953 English language edition of the Theory of Money and Credit, Mises (2009 [1953]: 100) explains that the objective exchange-value "is the most important kind of value, because it governs the social and not merely the individual aspect of economic life." However, Mises is quick to point out that this objective exchange value "is not a property of the goods themselves, bestowed on them by nature, for in the last resort it also is derived from the human process of valuing individual goods" (2009 [1953]: 100).

Furthermore, in developing his regression theorem, Mises acknowledges that "a historically continuous component is contained in the objective exchange-value of money. The past value of money is taken over by the present and transformed by it; the present value of money passes on into the future and is transformed in its turn" (2009 [1953]: 111). However, Mises (2009 [1953]: 112, original emphasis) explains further that "any suggestion of a causal relationship between past and present prices must be decisively rejected", not only for non-monetary goods, but also for money:

"It is so far as the money prices of goods are determined by monetary factors, that a historically-continuous component is included in them without which their actual level could not be explained. This component, too, is derived from exchange-ratios which can be entirely explained by reference to the subjective valuations of the individuals taking part in the market, even though these valuations were not originally grounded upon the specifically monetary utility alone of these goods. [...] The historically transmitted value is transformed by

\footnotetext{
${ }^{23}$ We are grateful to the anonymous referee who suggested clarifying this distinction.
} 
the market without regard to what has become its historical content" (Mises 2009 [1953]: 114, original emphasis).

Mises (2009 [1953]: 117) contended that Wieser put forth "a theory which attempts to explain variations in the objective exchange-value of money (objective innere Tauschwert des Geldes) by reference to the relationship that exists in an economic community between money income and real income." Mises viewed this as an insufficient attempt at a "complete theory of money — which, admittedly, the factors of supply and demand being excluded from consideration, would be certain to fail” (Mises 2009 [1953]: 117, original emphasis).

It is reasonable to argue then that the erroneous view that Wieser maintained, i.e. that the historical value of money rigidly conditions expectations of its future value, is part and parcel of this failed attempt, and may have further influenced Hayek in his view that entrepreneurs formulate production plans on the basis of recently past configurations of real prices. From this, Hayek argued, as we have seen before, that one-sided changes in the volume of money, albeit through their transient influence on prices, produce an almost automatic misallocation of resources.

Mises's account of the regression theorem and the ensuing theory of money he developed explicitly rejects the Wieser-Hayek view and explains that the structure of prices employed in economic calculation is constantly and inescapably subject to changes from the money-side of the economy that cannot be disentangled from the alterations occurring simultaneously on the real side. Neutral money theorists implicitly deny this point when they fall into the trap of identifying the unrealizable price structure of an imaginary barter economy, which is unsullied by the one-sided influences of money, as the norm for judging the performance of alternative monetary regimes. This led Mises (1966: 202) to characterize the assumption of neutral money as "a serious blunder that owes its origin and tenacity to a misinterpretation of this imaginary [barter] construction." 
Having argued that monetary calculation is the criterion of meaningfulness, as well as efficiency, for judging alternative economic systems, Mises confronted the question of whether variations in the value of money distort economic calculation and undermine the allocative efficiency of the pricing process. Decisively rejecting the construct of neutral money, Mises argued that in the actual market economy alterations in the relation between the demand for and supply of money continually occur and inevitably precipitate sequential and time-consuming adjustment processes that impinge on the structure of relative prices and incomes. The result is what Mises called "cash-induced" profits and losses that are indistinguishable from those associated with changes in relative prices. Yet any effects that these have on resource allocation can be ignored from the efficiency standpoint, precisely because neutral money is a contradiction in terms and economic calculation is inevitably monetary calculation, which can only proceed on the basis of a real-world money subject to dynamic market forces. As Mises (1966: 424-5) wrote, "the aims of monetary calculation are such that they cannot be frustrated by the inaccuracies which stem from slow and comparatively slight movements in purchasing power."

In other words, as a category of acting in the market economy, economic calculation implies the changeability of the value of money; it is therefore incorrect to argue that a money of variable purchasing power generates social inefficiency in the allocation of resources. Moreover, as Mises (1966: 224), pointed out, "Precision is unattainable in economic calculation quite apart from the shortcomings emanating from not paying due consideration to monetary changes." Specifically, the future prices and future costs of production which are the data of economic calculations are themselves uncertain, and even the outcome of past production decisions remains uncertain to the degree that capital accounting must rely on future-oriented appraisements of the prices of equipment and inventories. And yet, Mises 
(1966: 224) concluded, “economic calculation can achieve its tasks, [because such uncertainties] are inherent in the essence of acting that always deals with the uncertain future."

For Mises the market process at any moment is an organic entwinement of innumerable and interdependent adjustment processes — both real and monetary — in various stages of completion, which, in the very next moment, will be buffeted and displaced from its present course by fresh changes in the exogenous data. This market process is ordered and driven through time by entrepreneurs' monetary calculations oriented to market conditions as they will emerge at a future date in historical time. In other words, the fact that the nonneutral influences of money are always embedded in the historical market process and leave their imprint on the relative-price structure is no argument against the efficiency of monetary calculation, but merely an implication of the truth that the barter exchange ratios of general equilibrium are irrelevant for efficient action, and the only vehicle for economic calculation are money prices.

As a result, in this view, an ideal monetary system is not one that stabilizes the price level or neutralizes the influence of money on relative prices, since this is unattainable outside of the imaginary state of non-action or equilibrium — and thus irrelevant to the concerns of monetary calculation. This is in fact Mises's practical rebuttal of money neutrality, both in its early Wieserian and Hayekian, and later Lucasian and Patinkian versions.

Rather, a monetary system prescribed by this view is based on the norm of "sound money," which affirms the perfect suitability of market-originated commodity money for the purposes of economic calculation and enjoins the government from monetary interventions whose effect is to falsify and distort economic calculation. Explained Mises (1966: 223-4):

What economic calculation requires is a monetary system whose functioning is not sabotaged by government. The endeavours to expand the quantity of money in circulation either in order to increase the government's capacity to 
spend or in order to bring about a temporary lowering of the rate of interest disintegrate all currency matters and derange economic calculation.

For Mises, therefore, governmental "sabotage" of money has a very specific meaning: namely, the effect of persistent monetary expansion in falsifying economic calculation. This can occur in two ways. First, the government or its central bank may expand the money supply in order to finance large and persistent budget deficits associated with increased spending on war or reparations payments as occurred in Germany during and after the First World War. Such monetary policy ignites a "cycle of inflationary expectations" that eventually causes a hyperinflationary collapse of the monetary system. During the course of this cycle, inflationary expectations progressively take hold throughout the economy and eventually become completely "unanchored" from the monetary fundamentals. This development distorts consumption/saving decisions and grossly falsifies economic calculation of anticipated profits and capital values, causing resource allocation to become chaotic and the capital structure to disintegrate (Mises 1966: 426-8, 2006 [1923]: 1-14, Salerno 2010).

The second manner in which money is sabotaged, according to Mises, is when bank credit expansion drives the loan or money rate of interest rate below the rate consistent with voluntary consumption/saving or time preferences. This natural rate of interest is reflected in the equilibrium rate of return on capital investment. If the central bank orchestrates the expansion of bank credit and the suppression of the loan rate below the natural rate by continual creation of bank reserves, the falsification of monetary calculation is especially extended and severe, and entrepreneurs are encouraged to borrow the increased credit and make investments in lengthening the structure of production to a degree that is not sustainable by the available pool of voluntary savings. The sequence of effects that results from central 
bank manipulation of the interest rate is described in the Austrian theory of the business cycle, which was originated by Mises (2009 [1953]: 367-412, 2006 [1928]: 97-153). ${ }^{24}$

Mises (1966: 224) further maintained that the sound money norm denoted a fully attainable historical reality, i.e. the classical gold standard, which was "very different from the confused and self-contradictory program of stabilizing purchasing power. For the sake of economic calculation all that is needed is to avoid great and abrupt fluctuations in the supply of money. [Precious metals] served very well all the purposes of economic calculation." ${ }^{25}$ In this context, Mises (1966: 422) also argued that the concepts of inflation and deflation imply "the popular fallacy that there is such a thing as neutral money or money of stable purchasing power and that sound money should be neutral and stable in purchasing power." Accordingly, in contrast to Wieser and to Hayek, Mises did not fear that the increases in the value of money due to increases in "liquidity preference," which are bound to occur on occasion under the gold standard, would undermine the function of monetary calculation.

Mises argued that even if a change in the supply of money occurred that roughly matched a concurrent or prior change in the demand for money in the same direction, although it may leave the overall scale of prices roughly unchanged, it would not succeed in neutralizing the effect of the latter on relative prices and the social distribution of wealth. In fact, because these respective changes initially impinged on the economic system at different points, they would precipitate separate adjustment processes, each of which would exert its own non-neutral influence on the price structure. Thus, a central bank's attempt to head off

\footnotetext{
${ }^{24}$ Hayek held at first a similar view to Mises on the possibility and likelihood of national governments sabotaging the operations of the monetary system (cf. Caton 2018). In Denationalisation of Money, Hayek still argued, specifically citing Mises, that "It was not 'capitalism' but government intervention which has been responsible for the recurrent crises of the past" (Hayek 1978: 100). Nevertheless, he also diverged significantly from Mises by this time, calling for an ideal "rationally regulated world monetary system" (Hayek 1971: 74) made of competitive fiat currencies managed by a world government immune to inflation.

${ }^{25}$ For Mises, "great and abrupt fluctuations" refer to changes in the money supply that initiate the cycle of inflationary expectations. Also, unlike monetary injections directly into credit markets to reduce the loan rate of interest, the accretions of new money due to variations in the production of gold are not systematically introduced into credit markets and therefore do not necessarily distort interest rates and falsify economic calculation.
} 
deflation by responding to a fall in $V$ with a proportional increase in $M$ would not succeed in moving the economy closer to the neutral money ideal. According to Mises (2000 [1944b]: 120), "monetary fluctuations are not neutral, even apart from their repercussions on all contracts stipulating some form of deferred payments. Monetary changes are a source of economic and social change", which cannot be targeted or undone by monetary policies, but only compounded.

This point was acknowledged by Hayek (1967 [1935]: 124), who did not, however, fully recognize that quantitatively adapting the supply of money brings about a new host of economic and social changes without ever neutralizing the initial effects of changes in the value of money:

in order to eliminate all monetary influences on the formation of prices, and the structure of production, it would not be sufficient merely quantitatively to adapt the supply of money to these changes in demand, it would be necessary also to see that it came into the hands of those who actually require it, i.e., to that part of the system where that change in business organisation or the habits of payment had taken place.

For this reason, in their practical recommendations, Hayek allowed for monetary authorities to intervene in cases of an acute crisis to compensate the effects of deflation (Hayek 1967 [1935]: 298) —a suggestion which Mises deemed not only practically impossible, but theoretically untenable as well.

Let us now turn to an examination of Menger's attitude toward the notion of a money that has no effect on the course of development of real variables.

\section{Carl Menger}

Like Mises, Menger was indirectly implicated by later writers as a forerunner of the neutralmoney tradition. We would argue that Menger had in fact originated the view that economic calculation and efficient resource allocation could only be predicated on money prices and that 
the general pricing process itself was inevitably shaped by monetary forces. However, Menger's theory of money was incomplete (Chaloupek 2003); as Sennholz (1992: 25) explained, Menger "did not have the opportunity or inclination to analyze the various determinants of the objective exchange value of money. He offered no explanation of the process of value determination at any given time and place. Menger left this task to Friedrich von Wieser and Ludwig von Mises."

Whereas Mises was able to explain and clarify his own position on this matter, Menger's views needed to be posthumously defended against misinterpretation by monetary theorist Arthur Marget. Marget (1966, 2: 66-9) explained:

[Menger's] discussion was such as to emphasize, rather than to minimize, the importance of money in the functioning of the economic process... He did not argue, either explicitly or by implication, that a satisfactory 'general' theory of pricing should or could be constructed upon the basis of barter assumptions... [Menger's] own distinction [between internal and external value of money] was to emphasize the fact that both 'monetary' and 'non-monetary' factors are of such far-reaching importance for price formation that one must be continually on one's guard against specious attempts to explain a given set of price movements in terms of either 'monetary' or 'non-monetary' factors alone. He argued, in short, that any attempt to explain the 'movement of commodity prices' requires at every step in the process, not only the weapon of monetary theory, in the narrower sense of the term, but also the whole of the apparatus of 'general' [money] pricing theory.

With his analytical focus set on the real-world pricing process, Menger eschewed the notion of monetary neutrality as an efficiency standard and — instead of dwelling on the alleged efficiency properties of the price system of a barter economy-he elaborated the role of money prices as the indispensable tool of economic calculation and rational resource allocation in a dynamic world. Indeed, in Menger's revised article on money for the third edition of the Handwörterbuch der Staatswissenschaften, we find a long discussion of the 
benefits of money prices for the evaluation of the means and results of economic activity. ${ }^{26}$ This emphasis is completely absent in Wieser's later article on money for the fourth edition of the Handwörterbuch (Wieser 1926).

Menger (1970 [1909]: 65) characterized the money unit "as a measure not of the quantity of exchange value contained in goods but rather of money prices, in the very sense in which the money unit $[\ldots]$ is the measure of all other monetary quantities." In other words, prices expressed in terms of the money unit "provide at least a valuable reference point for judging the actual exchange relations of market goods and their variations on the same market, and likewise for comparing the exchange relations of goods on different markets." For this reason, it is only the dynamic, money-using, historical market economy and not the fictional barter economy that fulfils the calculational preconditions of rational or purposeful action under the division of labour.

Moreover, Menger (1970 [1909]: 72) points out that the benefits of monetary calculation and the importance of money prices increase further, the more general the use of money in exchange (“je allgemeiner das Geld seine vermittelnde Funktion im Verkehre übt”), the higher the dependence of individuals and groups on the market due to an extension of the division of labour and the monetary economy ("je grösser mit der Entwicklung der Arbeitsteilung und der Geldwirtschaft die Abhängigkeit der einzelnen Wirtschaften vom Markte") and finally the more stable and secure the monetary system of a country ("je grösser endlich die Sicherheit und die Stabilität des Geldwesens eines Landes sind").

Monetary calculation enables the confrontation of an action's costs with its benefits and the ascertainment of the quantity of the means available to the agent for future action, i.e.,

\footnotetext{
${ }^{26}$ In his own words, money prices provide a "ungleich übersichtlicheres und genaueres Mass der Mittel und Erfolge der Wirtschaft [more clear-cut and exact measurement of inputs and results of economic activities]" (Menger 1970 [1909]: 71). For the whole discussion of the benefits of money prices, see Menger (1970 [1909]: 66-73), in particular, subsection 3 entitled Die praktische Bedeutung der Bewertung der Güter in Geld ("The practical significance of the valuation of goods in money"). We use Leland B. Yeager with Monika Streissler's translation of the text (Menger 2002 [1909]).
} 
his wealth or capital. As Menger (1970 [1909]: 66) expressed it, “[e]stablishing a measure of the inputs and results of economic activities, one's own and those of persons with whom we are connected by business or have other social relations, is of the greatest practical importance in very many cases of private and public life [...]; indeed it is the foundation and prerequisite of purposive action." In a barter economy, rational economic calculation and the measurement of wealth and income are wrought with many difficulties.

Menger (quoted in Endres 1987: 304) hinted at the inextricable link between monetary calculation and capital by defining the latter as "the productive property, whatever technical nature it may have, so far as its money value is the subject of economic calculation, that is if it appears in our accounting as a productive sum of money." ${ }^{27}$ And Menger (1977: 12) also implied that monetary calculation itself constitutes a realistic standard of economic efficiency, which "facilitates a clear and accurate measure of means and results of economic life and by far exceeds that of the barter process."

In this analysis of Menger's we find the kernel of Mises's monetary analysis which emphasizes the non-neutrality of money. For Menger, as for Mises later on, money prices exist in the market economy only after a general medium of exchange emerges and monetary exchanges take place. The price structure then reflects the relation between the supply of and demand for money in a way in which money-side changes are simultaneous and indistinguishable from real-side changes. There is no 'shadow', real, or natural barter price structure, unsullied by the one-sided influences, which lurks under the monetary price structure that can be used as a norm for judging the performance of alternative monetary regimes. Menger made this clear when he wrote that:

\footnotetext{
${ }^{27}$ In the original, we read: "Der Realbegriff des Kapitals umfaßt das Vermögen der Erwerbswirtschaft, welcher technischen Natur dasselbe an sich auch sein mag, insofern sein Geldwert Gegenstand unseres ökonomischen Kalküls ist, d. i. wenn dasselbe sich uns rechnungsmäßig als eine werbende Geldsumme darstellt" (Menger 1935 [1888]: 174).
} 
Wherever barter in the narrow sense of the term disappears, and only sums of money (for the most part) actually appear as prices of the various commodities, a reliable basis for valuation in any but monetary terms is lacking. The valuation of grain or wool, for example, is relatively simple in terms of money. But the valuation of wool in terms of grain, or of grain in terms of wool, involves greater difficulties, if for no other reason than because a direct exchange of these two goods never takes place... Valuation in terms of other commodities is a more complicated procedure that presupposes prior valuations in terms of money (Menger 2007 [1976]: 276; emphasis added).

In fact, Menger introduced the distinction between "the external exchange value of money" and "the internal exchange value of money" in order to emphasize the inextricable link between money and the real sphere. For Menger (2002 [1909]: 64-65) the external exchange value of money refers to "the general purchasing power of money" or "the exchange value [of money] expressed in commodities." Money's external value or purchasing power is thus embedded in the actual array of money prices emerging on the market at any moment and cannot be separated from it. Menger (2002 [1909]: 67) explicitly recognized that all market prices are co-determined by factors in the real sphere and the money sphere: "The exchange ratios between goods traded and money are always the result of determining factors both on the side of goods and on the side of money." In other words, changes in the "internal value of money," which occur as a result of autonomous variations in the supply of or demand for money, influence market prices in the same way as changes that originate strictly in the markets for goods.

Menger (2002 [1909]: 68-70) argued furthermore that it was almost inconceivable that the internal exchange value of money would always remain invariant and therefore neutral to the pricing process. This is especially true when money itself consists of a good produced on the market such as gold or silver:

Any impartial analysis of market phenomena makes us recognize the far 
-reaching influence exerted on the exchange ratio between money and the goods traded by the variations in the quantity of money in circulation, the variations in the economy's demand for circulating media, the increasing or decreasing production costs of the money metals, the more or less increasing use of document money [Urkundengeld], and many other changes in the determining factors of price formation occurring only on the side of money... Ever since precious-metal money was also recognized as an object of trade influenced by the factors determining price formation, monetary theorists have been striving to discover some other market good whose exchange ratio against other goods is not influenced by determining factors on the side of this good... [T] hey are looking for a good of universal and invariable 'inner exchange value ${ }^{28} \ldots$ Yet it is likewise beyond all doubt that no object of trade is to be found on our markets whose exchange ratio against all other goods remains invariant over time, nor is there one for which the price-modifying influences operating on the other objects of trade do not assert themselves at all (thus, on our markets there is no object of trade whose 'outer' nor one whose 'inner exchange value' is the same everywhere and at all times). At this point there emerges a tension in Menger's exposition that might be at the root of diverging interpretations of his writings. Menger (2002 [1909]: 63) makes it very clear that the quest for a universally stable external exchange value of money, across time and space, is illusory. He writes that the "search for a solution to [this] problem, which has often and indeed not without good reason been called the squaring of the circle in economics, turns out, however, to be hopeless. ${ }^{29}$ On the other hand, he does not in principle reject the possibility of stabilizing the internal exchange value of money and he admits that the latter might have some benefits. ${ }^{30} \mathrm{He}$ argues that the problem of a stable internal exchange value is "incomparably simpler" (Menger 2002 [1909]: 70) than the problem of a stable external exchange value. This

\footnotetext{
${ }^{28}$ Note that in this quotation the translators have chosen to render Menger's terms "innerer Tauschwert" and "äußerer Tauschwert" more literally as the "inner exchange value" and "outer exchange value," respectively, while we use the terms "internal exchange value" and "external exchange value" in the text.

${ }^{29}$ In the original: "Die Untersuchung über das obige Problem, dem vielfach und, zwar nicht ohne guten Grund, die Bezeichnung der nationalökonomischen Quadratur des Zirkels zu teil geworden ist, erweist sich indes als aussichtslos" (Menger 1970 [1909]: 74).

${ }^{30}$ Menger (1970 [1909]: 85) writes that "die Möglichkeit eines Gutes von stabilem inneren Tauschwerte ist prinzipiell nicht schlechthin ausgeschlossen [a good of stable exchange value is not utterly unthinkable.]."
} 
simpler problem needs to be solved, if it is to be solved at all, by government regulation, since there is no good with constant internal exchange value on the free market (Menger 2002 [1909]: 70-71).

Hence, despite the inextricable link between external and internal exchange value of money highlighted in another part of Menger's exposition, he also suggests that it might, in principle, be possible to have a money with fluctuating external and stable internal exchange value. He was, however, given the state of scientific knowledge, very sceptical about the possibility, in practice, of reliably identifying and quantifying the changing causes on the money-side. This, however, would be necessary to implement the corresponding monetary policy to offset these changes without distorting the real-side.

Indeed, he calls the necessary assumptions that have to be made in order to be able to identify and quantify the changing causes on the money-side "so far-fetched". They are "so hard to test that even the most sensible methods of applying this idea cannot lead to an entirely satisfactory result. All methods of identifying interlocal differences and the movement of the inner exchange value of money that are based on this presupposition are even basically arbitrary and unsupported." ${ }^{\prime 31}$

In consequence, Menger was a proponent of a gold standard for the Austro-Hungarian Empire, because it represented a practical means for realizing the real efficiencies of monetary calculation. In contrast to Wieser (1926), he would not - not even as a hypothetical ideal suggest a paper money standard. However, he would recognize certain benefits to fiduciary elements in the money supply that automatically, that is, without direct government interference, push money towards a more stable exchange value (Menger 2002 [1909]: 84-8). When given the choice between non-intervention into the monetary sphere and a money

\footnotetext{
${ }^{31}$ In the original: “ [...] so künstlich, auch so schwer zu kontrollieren, dass selbst die sinnreichsten Methoden der Durchführung dieses Gedankens zu keinem ganz befriedigenden Ergebnisse führen können. Alle auf der obigen Voraussetzung fussenden Methoden zur Bestimmung der örtlichen Verschiedenheit und der Bewegung des inneren Tauschwertes des Geldes sind schon i[m] Prinzipe willkürlich und unverbürgt." (Menger 1970 [1909]: 90-1)
} 
imposed by government force, Menger would have opted for the former, ${ }^{32}$ although he thought that the ideal lies somewhere in between, that is, his ideal was a market-based money polished by government regulation. ${ }^{33}$

\section{Conclusion}

This paper disentangles the evolution of two views on the neutral money concept in neoclassical economics. We have shown that Mises's and Menger's views on money pose an antithetical view to the intellectual kinship between Hayek and Wieser on the imaginary construct of a money-using economy in which monetary factors have no influence in shaping real variables. The Mengerian and Misesian views provide a more fundamental critique of the concept which rests on understanding money's integral role in the market's pricing process and in entrepreneurs' calculational procedures. This provides a stronger foundation for critiques of the neutral money doctrine than that of modern studies by offering an alternative way of monetary theorizing - one which integrates the analysis of direct and indirect exchange instead of accepting the shadow "real" or "natural" prices assumption.

${ }^{32}$ Menger (1970 [1909]: 106) writes:

Die prinzipielle Zurückweisung des Zwangskurses ist ebensowohl ein Irrtum wie die prinzipielle Forderung desselben. Indes scheint mir die erstere denn doch den geringeren Irrtum in sich zu schliessen. Kann nämlich den prinzipiellen Gegnern des Zwangskurses mit Recht entgegengehalten werden, dass sie das, was im grossen und ganzen eine (von berechtigten Ausnahmen durchbrochene) Regel praktischer Wirtschaftspolitik ist, zu einem ausnahmslosen Gesetze verallgemeinern: so den Verfechtern des prinzipiellen Zwangskurses, dass sie dasjenige, was nur für gewisse Ausnahmefälle sich als nützlich oder notwendig erweist, zur allgemeinen Regel [...] erheben.

In Yeager and Streissler's translation:

To reject legal tender on principle is just as much an error as to demand it on principle. It seems to me, though, that the former involves the lesser error. For while it may rightly be held against those who oppose legal tender on principle that they generalize what is a rule (on the whole, with justified exceptions) of practical economic policy into a law without exception, it may be held against those who advocate legal tender on principle that they turn something that proves useful or necessary only in certain exceptional cases into a general rule - indeed, by including legal tender in the very concept of money, into a law without exception. (Menger 2002 [1909]: 83)

33 That Menger assigned a stronger role to government in his 1909 encyclopedia entry than in his earlier writings was also highlighted by Ikeda (2008). A very firm position in favor of sound money and skepticism towards government intervention came through in Menger's Lectures to Crown Prince Rudolph, delivered at a time when he was a relatively young professor at the University of Vienna (Menger 1994 [1876]). 
Furthermore, we have also shown that although the Wieser-Hayek view of neutral money is widespread among modern monetary and macroeconomists, it is often adopted in a much less nuanced version than either of its originators intended — each of whom had significant doubts surrounding the practicability and feasibility of a monetary system with neutral money or neutral monetary policy.

These two conclusions thus shape up to a fresh challenge to the current purpose and form of monetary policies around the world, whose aim is precisely to make money neutral. However, if this purpose is at best highly impracticable, and most likely unrealizable, then the credibility and chances of success of such policies become problematic. This underscores once more the importance of seriously reconsidering the doctrinal foundations of modern monetary theory not only to illuminate, but hopefully even to completely shift the focus of modern monetary policy.

\section{REFERENCES}

Abel, A. B. and Bernanke, B.S. (1992). Macroeconomics. New York: Addison-Wesley Publishing Company, Inc.

Anderson, B. M. (1917). The Value of Money. Grove City, PA: Libertarian Press, Inc.

Boianovsky, M. (1993) "Bohm-Bawerk, Irving Fisher, and the Term "Veil of Money": A Note", History of Political Economy, 25(4): 725-738.

Caton, J. (2018) "The Evolution of Hayek's Thought on Gold and Monetary Standards", AIER Sound Money Project Working Paper No. 2018-06, January 26.

Chaloupek, G. (2003) "Carl Menger's contributions to the Austrian currency reform debate (1892) and his theory of money", Paper presented to the 7. ESHET Conference, Paris, January 30 to February 1, 2003 (parallel session F 3).

Chaloupek, G. (2010). "Neutrality Of Money" versus "Stability Of The Price Level" - Issues Of Monetary Theory Within The Austrian School Of Economics. Paper presented to the 14th. ESHET Conference, Amsterdam, March 25-27. 
Chetwin, W. and Wood, A. (2013). Neutral Interest Rates in the Post-Crisis Period, Reserve Bank of New Zealand Analytical Note Series, AN2013/07 (November).

Cheng, W. and Angus, S.D. (2012). Cantillon Effect of Monetary Injection through Deficit Spending, Department of Economics Discussion Papers 12/12, Monash University.

Dullaart, M.H.J. (1988). Wieser's Theory of Money. Journal of Economic Studies. 15 (3/4): 123-35.

Ebeling, R. (2014) Hayek and Mises: From Vienna Days to Conceptions of the Market Process, in Garrison, R. and N. Barry, The Elgar Companion to Hayekian Economics, Cheltenham: Edward Elgar, pp. 138-64.

Ellis, H. S. (1934). German Monetary Theory 1905-1933. Cambridge, MA: Harvard University Press.

Endres, A. M. (1987). The Origins of Böhm-Bawerk's 'Greatest Error': Theoretical Points of Separation from Menger. Journal of Institutional and Theoretical Economics 143 (June), 291-309.

Federal Reserve Bank of New York. (2016). Measures and Policy Applications of the Equilibrium Neutral Real Interest Rate [online] PBOC-FRBNY Joint Symposium, available at

https://www.newyorkfed.org/medialibrary/media/research/economists/delnegro/delnegro_frb nydsge_pboc.pdf

Greidanus, T. (1932). The Value of Money: A discussion of Various Monetary Theories, And an Exposition of the Yield Theory of the Value of Money. London: S. King \& Son, Ltd.

Halm, G. (1946). Monetary Theory: A Modern Treatment of the Essentials of Money and Banking. $2^{\text {nd }}$ ed. Philadelphia: The Blakiston Company.

Hamilton, J. D., Harris, E.S., Hatzius, J., and West, K.D. (2015). The Equilibrium Real Funds Rate: Past, Present, and Future, US Monetary Policy Forum, New York, February 27.

Hayek, F. A. (1952) [1941]. The Pure Theory of Capital. Chicago: The University of Chicago Press.

(1966) [1933]. Monetary Theory and the Trade Cycle. Translated by N. Kaldor and H. M. Croome. New York: Augustus M. Kelley Publishers.

Publishers.

(1967) [1935]. Prices and Production. $2^{\text {nd }}$ ed. New York: Augustus M. Kelley

(1969) [1939]. The Paradox of Saving. In: F.A. Hayek, Profits, Interest and Investment and Other Essays on the Theory of Industrial Fluctuations. New York: Augustus M. Kelley Publishers. 199-263.

. (1971) [1937]. Monetary Nationalism and International Stability. New York:

Augustus M. Kelley Publishers. 
. (1972) [1943]. A Commodity Reserve Currency. In: F.A. Hayek, Individualism and Economic Order. Chicago: Henry Regnery Company. 77-91.

. (1972) [1945]. The Use of Knowledge in Society. In: F.A. Hayek, Individualism and Economic Order. Chicago: Henry Regnery Company. 77-91.

. (1975). A Discussion with Friedrich A. von Hayek, Domestic Affairs Study 39, Washington, DC: American Enterprise Institute for Public Policy Research.

(1978). Denationalisation of Money-The Argument Refined: An Analysis of the $\overline{T h e o r y}$ and Practice of Concurrent Currencies. $2^{\text {nd }} \mathrm{ed}$. London: The Institute of Economic Affairs.

. (1984) [1933]. On Neutral Money (Über 'neutrales Geld'). In: F.A. Hayek, Money, Capital, and Fluctuations: Early Essays. Ed. Roy McCloughry. Chicago: The University of Chicago Press. 159-62.

(1985). New Studies in Philosophy, Politics, Economics and the History of Ideas, $2^{\text {nd }}$ ed., Chicago: University of Chicago Press.

. (1992) [1926]. Friedrich von Wieser (1851-1926). In: P.G. Klein (ed.), The Collected Works of F. A. Hayek. Vol. 4: The Fortunes of Liberalism: Essays on Austrian Economics and the Ideal of Freedom. Chicago: University of Chicago Press. 108-25.

. (1995) [1932]. Reflections on the Pure Theory of Money by Mr. J.M. Keynes (continued), In: The Collected Works of F. A. Hayek. Vol. 5: Contra Keynes and Cambridge: Essays, Correspondence, Chicago: University of Chicago Press. 174-98.

(2012). The Collected Works of F.A. Hayek: Business Cycles, Part I, ed. Hansjoerg Klausinger, Carmel, IN: Liberty Fund, Inc.

Horwitz, S. (2016). Hayek on the Neutrality of Money. In: Studies in Austrian Economics: Advances in Austrian Economics, vol. 2, pp. 61-78.

Hülsmann, J.G. (2007). Mises: The Last Knight of Liberalism. Auburn, AL: Ludwig von Mises Institute.

Ikeda, Y. (2008). Carl Menger's Monetary Theory: A Revisionist View. European Journal of the History of Economic Thought, 15(3), 455-473.

Kaldor, N. (1970). The New Monetarism. Lloyds Bank Review, 97(1): 1-17.

Klausinger, H. (1990). The Early Use of the Term "Veil of Money" In: Schumpeter's Monetary Writings: A Comment on Patinkin and Steiger, The Scandinavian Journal of Economics, 92(4): 617-21.

Klein, L. R. (1947). The Use of Econometric Models as a Guide to Economic Policy, Econometrica, 15(2): 111-51. 
Koopmans, J. G. (1933). Zum Problem des 'Neutralen' Geldes. In: F. A. Hayek, Beiträge zur Geldtheorie, Vienna: Springer.

Laidler, D. (1990). Money as a Metaphorical Garment before the Great War: A Comment on Patinkin and Steiger, The Scandinavian Journal of Economics, 92(4): 613-5.

Laubach, T. and Williams, J.C. (2015). Measuring the Natural Rate of Interest Redux, Working Paper 2015-16 (October), Federal Reserve Bank of San Francisco.

Lines, M. and Westerhoff, F. (2010). Inflation Expectations and Macroeconomic Dynamics: The Case of Rational versus Extrapolative Expectations, Journal of Economic Dynamics and Control, 34(2): 246-57.

Lubik, T. A. and Matthes, C. (2015). Calculating the Natural Rate of Interest: A Comparison of Two Alternative Approaches, Federal Reserve Bank of Richmond Economic Brief, October 2015, EB15-10.

Lucas, R. E. (1975). An Equilibrium Model of the Business Cycle, Journal of Political Economy, 83(6): 1113-44.

Lutz, F. A. (1969). On Neutral Money. In E. Streissler, G. Haberler, F. A. Lutz, and F. Machlup, Roads to Freedom: Essays in Honor of Friedrich A. von Hayek. London: Routledge \& Kegan Paul Limited. 105-115.

Mankiw, G. N. (2003). Macroeconomics. $5^{\text {th }}$ ed. New York: Worth Publishers.

Mankiw, G.N. and Reis, R. (2002) Sticky Information versus Sticky Prices: A Proposal to Replace the New Keynesian Phillips Curve, Quarterly Journal of Economics 117(4), 1295 328.

Marget, A. W. (1966) [1938-1942]. The Theory of Prices: A Re-Examination of the Central Problems of Monetary Theory. 2 vols. New York: Augustus M. Kelley Publishers.

McCallum, B. T. (1980). Rational Expectations and Macroeconomic Stabilization Policy: An Overview, Journal of Money, Credit and Banking, 12(4): 716-46.

Meltzer, A. (1988). Keynes's Monetary Theory: A Different Interpretation, New York: Cambridge University Press.

Menger, C. (1935) [1888]. Theorie des Kapitals. In Kleinere Schriften zur Methode und Geschichte der Volkswirtschaftslehre (pp. 135-183). London: London School of Economics.

. (1970) [1909]. Geld. In F. A. von Hayek (Ed.), Carl Menger Gesammelte Werke Band IV: Schriften über Geld und Währungspolitik (pp. 1-116). Tübingen: J. C. B. Mohr.

(1994) [1876]. Carl Menger's Lectures to Crown Prince Rudolph of Austria. Ed. Erich W. Streissler and Monika Streissler. Translated by Monika Streissler and David F. Good. Brookfield, VT: Edward Elgar Publishing Company. 
(2002) [1909] "Money." Translated by Leland B. Yeager with Monika Streissler. In Michael Latzer and Stefan W. Schmitz, Carl Menger and the Evolution of Payments Systems: From Barter to Electronic Money (pp. 25-108). Northampton, MA: Edward Elgar

. (2007) [1976] Principle of Economics, Translated by J. Dingwall and B. F. Hoselitz, Auburn, AL: Ludwig von Mises Institute.

Milhoj, M. O. and Fischer, A.V. (2015). The Fed's Theoretical Thinking and the Importance of the So-Called Neutral Real Interest Rate [online], Danske Bank, December 9, available at http://danskeresearch.danskebank.com/abo/FedTheoreticalThinking091215/\$file/FedTheoreti calThinking_091215.pdf.

Mises, L. von. (1912). Theorie des Geldes und der Umlaufsmittel. München und Leipzig: Duncker \& Humblot. Company. (1966). Human Action: A Treatise on Economics. 3rd. ed. Chicago: Henry Regnery . (1990) [1932) The Position of Money among Economic Goods. In Money, Method, and the Market Process: Essays by Ludwig von Mises. Ed. Richard M. Ebeling. Norwell, Mass.: Kluwer Academic Publishers. 55-68.

. (1990) [1938]. The Non-Neutrality of Money. In Money, Method, and the Market Process: Essays by Ludwig von Mises. Ed. Richard M. Ebeling. Norwell, Mass.: Kluwer Academic Publishers. 69-77.

. (2000) [1944a]. Postwar Reconstruction, In Selected Writings of Ludwig von Mises, vol. 3: The Political Economy of International Reform and Reconstruction, Ed. R. Ebeling, Indianapolis: Liberty Fund. 1-20.

. (2000) [1944b]. The Main Issues in Present-Day Monetary Controversies, In Selected Writings of Ludwig von Mises, vol. 3: The Political Economy of International Reform and Reconstruction, Ed. R. Ebeling, Indianapolis: Liberty Fund. 119-132.

(2002) [1924] The Return to the Gold Standard, In Selected Writings of Ludwig von Mises, vol. 2: Between the Two World Wars: Monetary Disorder, Interventionism, Socialism, and the Great Depression, Ed. R. Ebeling, Indianapolis: Liberty Fund. 136-53.

2002 [1931] The Gold Standard and its Opponents, In Selected Writings of Ludwig von Mises, vol. 2: Between the Two World Wars: Monetary Disorder, Interventionism, Socialism, and the Great Depression, Ed. R. Ebeling, Indianapolis: Liberty Fund. 174-81.

(2006) [1923]. Stabilization of the Monetary Unit - From the Viewpoint of Theory. In The Causes of the Economic Crisis and Other Essays Before and After the Great Depression. Ed. Percy L. Greaves, Jr. Auburn, AL: Ludwig von Mises Institute. 1-51.

. (2006) [1928]. Monetary Stabilization and Cyclical Policy. In The Causes of the Economic Crisis and Other Essays Before and After the Great Depression. Ed. Percy L. Greaves, Jr. Auburn, AL: Ludwig von Mises Institute. 53-153. 
. (2009) [1953]. The Theory of Money and Credit. Translated by H. E. Batson.

Indianapolis: Liberty Classics.

. (2012 [1913a]) The General Rise in Prices in Light of Economic Theory, In Selected

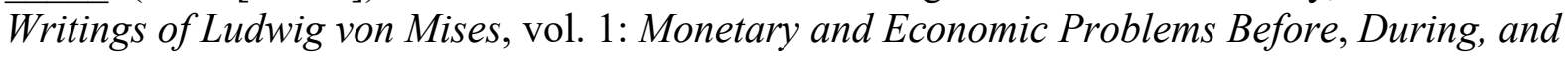
After the Great War, Ed. R. Ebeling, Indianapolis: Liberty Fund. 131-55.

. (2012 [1913b]) On Rising Prices and Purchasing Power Policies, In Selected Writings of Ludwig von Mises, vol. 1: Monetary and Economic Problems Before, During, and After the Great War, Ed. R. Ebeling, Indianapolis: Liberty Fund. 156-67.

. (2012 [1919]) Monetary Devaluation and the National Budget, In Selected Writings of Ludwig von Mises, vol. 1: Monetary and Economic Problems Before, During, and After the Great War, Ed. R. Ebeling, Indianapolis: Liberty Fund. 235-39.

Öğünç, F. and Batmaz, İ. (2011). Estimating the Neutral Real Interest Rate in an Emerging Market Economy. Applied Economics, 43 (6): 683-93.

Patinkin, D. (1965) Money, Interest and Prices: An Integration of Monetary and Value Theory. 2nd ed. New York: Harper \& Row.

Patinkin, D. and Steiger, O. (1989). In Search of the "Veil of Money" and the "Neutrality of Money": A Note on the Origin of Terms. The Scandinavian Journal of Economics, 91(1): $131-46$.

Perrelli, R. and Roache, S.K. (2014). Time-Varying Neutral Interest Rate-The Case of Brazil. IMF Working Paper WP/14/84 (May).

Pescatori, A. and Turunen, J. (2015). Lower for Longer: Neutral Rates in the United States. IMF Working Paper WP/15/135 (June).

Roll, E. (1936). Menger on Money, Economica New Series, 3(12): 455-60.

Salerno, J. T. (1999). The Place of Human Action in the Development of Modern Economic Thought. The Quarterly Journal of Austrian Economics 2 (Spring): 35-65.

. (2002). Friedrich von Wieser and Friedrich A. Hayek: The General Equilibrium Tradition in Austrian Economics. Journal des Economistes et des Etudes Humaines 12 (June/September): 357-77.

(2010). Ludwig von Mises on Inflation and Expectations. In: J.T. Salerno, Money, Sound and Unsound. Auburn, AL: Ludwig von Mises Institute. 199-236.

. (2012). A Reformulation of Austrian Business Cycle Theory in Light of the Financial Crisis, Quarterly Journal of Austrian Economics 15 (1): 3-44.

(2016) The Fed and Bernanke Are Wrong About the Natural Interest Rate, [online] Mises Wire, June 26, available at https://mises.org/wire/fed-and-bernanke-are-wrong-aboutnatural-interest-rate. 
Schumpeter, J. A. (1968) [1954]. History of Economic Analysis. New York: Oxford University Press.

\section{Press.}

(1969). Ten Great Economists: From Marx to Keynes. New York: Oxford University

Samuelson, P. A. (1958). An Exact Consumption-Loan Model of Interest With or Without the Social Contrivance of Money. Journal of Political Economy, 66(6): 467-82.

Sargent, T. and Wallace, N. (1976). Rational Expectations and the Theory of Economic Policy. Journal of Monetary Economics 2(2): 169-83.

Selgin, G. (1999). Hayek versus Keynes on How the Price Level Ought to Behave, History of Political Economy 31(4): 699-721.

Sennholz, H. (1992). The Monetary Writings of Carl Menger. In L.H. Rockwell (ed.), The Gold Standard: Perspectives in the Austrian School. $2^{\text {nd }}$ ed. Auburn, AL: Ludwig von Mises Institute.

Wicksell, K. (1962) [1936]. Interest and Prices. Translated by R.F. Kahn. New York: Royal Economic Society.

White, L. H. (1993). The Monetary Economics of F. A. Hayek. Paper prepared for the Liberty Fund symposium The Legacy of F. A. Hayek, Chicago, Ill., November.

Wieser, F. von. (1926). Geld (Theorie des Geldes). Handwörterbuch Der Staatswissenschaften. Band 4, 681-717.

. (1929) [1904]. Der Geldwert und seine geschichtlichen Veränderungen. Gesammelte Abhandlungen, edited by Hayek, F. von. Tübingen: J. C. B. Mohr. pp. 164-192.

. (1929) [1909a]. Der Geldwert und seine Veränderungen. Gesammelte Abhandlungen, edited by Hayek, F. von. Tübingen: J. C. B. Mohr. pp. 193-242.

. (1929) [1909b]. Über die Messung der Veränderungen des Geldwertes. Gesammelte Abhandlungen, edited by Hayek, F. von. Tübingen: J. C. B. Mohr. pp. 243-252.

. (1967) [1927]. Social Economics. Translated by A. Ford Hinrichs. New York:

Augustus M. Kelley Publishers.

(1971) [1893]. Natural Value. New York: Augustus M. Kelley Publishers.

Williams, J. C. (2003). The Natural Rate of Interest, Economic Letter 2003-32, Federal Reserve Bank of San Francisco October 31.

60 .

(2015). The Decline in the Natural Rate of Interest, Business Economics, 50(2): 57- 
Yellen, J. L. (2005). Update on the U.S. Economy, Presentation to a Salt Lake City Community Leaders Luncheon [online], October 18, Salt Lake City, Utah, available at http://www.frbsf.org/our-district/files/051018.pdf. 